friend and myself might be perfectly satisfied of the identification of this rock-type. The fact that such rocks occur as boulders in the clay had long been a matter of common knowledge, and half an hour's work at the cliffs will always produce specimens of this angite-syenite and of the equally characteristic rhomb-porphyry, the two most striking rocks among the beach material. Surely it would $b_{e}$ " more in accordance with scientific laws of evidence" to ascertain the facts of the case, either personally or from the records, before propounding an artificial explanation of them.

If further evidence be needed, I may add that $I$ have recently sliced and examined typical specimens of the two unique Scandinavian rocks mentioned above, which were collected at Cambridge by Professor Hughes.

St. John's College, Cambridge, June 2 nd, 1894.

Alfred Harker.

\title{
UNIFORMITY IN GEOLOGY AND THE ORIGIN OF THE DRIFT.
}

Sir,-Sir Henry H. Howorth opens a rather strangely reasoned paper in your last month's issue with the statement that signs are. accumulating everywhere that geologists are now harking back to the views of the old catastrophists, and giving up the uniformitarian views so ably placed on record by Lyell and later workers. Where these signs are to be seen $I$ am at a loss to discover. Certainly not in the Nottingham Address of Mr. J. J. Harris Teall to the geological section of the British Association, nor yet in the text-books and original papers written during the last fow years. No doubt popular magazine writers will to some extent regard Sir Henry H. Howorth's writings as being one of the signs of the times, and will be ready to put his ideas before their readers as "recent advances." Every supporter of uniformitarian principles admits that floods and earthquakes have always occurred. Nor am I aware that any exact limit has been fixed to their magnitude. At least I never heard it argued that the eruption of Krakatoa, for example, was the greatest outburst that has ever occurred, or that there will never be a greater. It only asks us to seek to explain the facts by slow and well-known causes that may be seen in everyday action rather than by extreme or violent means. For instance, the great majority of geologists consider that the distribution of the drifts can be best accounted for on the assumption that large portions of the northern continents were covered by immense ice-fields. Judging from the present distribution of glaciers and ice-fields, etc., Sir Henry H. Howorth thinks this view extreme and not sufficiently uniformitarian, and pins his faith on floods and dancing mountain ranges. The time has gone by for a general discussion on this point. If a particular deposit can only be explained on the assumption that there was a deluge, we must believe that there was a deluge. It would be unscientific to settle upon the agent first and then point to all sorts of deposits as being produced by it.

But, to return to the paper, my intention was also to refer to 
two letters which appeared in "Nature," and which Sir Henry $H$. Howorth quotes. One was from the pen of Professor Bonney. In it he asks whether the fact that there is a deep submarine channel along the coast of Norway does not render it improbable that the ice-sheet could have crossed it and reached Great Britain. Professor Bonney very wisely does not say that it could not, for he would be a rash man who would say what the snowfall was upon the mountains, and how far the ice would have to move from them before it melted, and the law of supply and wasting was satisfied. However, on the strength of the fact that the question has been asked, we learn that "Prof. Bonney has added a new and striking" objection, "based upon the difficulty an ice-sheet would have in traversing the hollow trough."

Another letter, also published in "Nature," and written by Prof. Hughes, is also referred to. In this letter Prof. Hughes calls attention to the fact that on such coasts as that of Norfolk great care should be taken, when collecting rock-specimens from the drift, that the boulders are really from the drift, and not ballast thrown overboard or spread along the coast by the wreck of a vessel. When I read the letter I thought it was addressed as a warning to some careless student, but we now hear from Sir Henry H. Howorth that it is an expression of opinion on the part of Prof. Hughes that the officers of the Geological Survey, and other experienced field geologists, who have visited the coast have not been alive to such possibilities.

I should like to notice the rest of the paper, but to do so would require too much space, Sir Henry H. Howorth having treated the drifts as a hotch-potch of mud, sand, and gravel, instead of a series of deposits formed at different times and under different circumstances.

R. M. Deeley.

\section{JURASSIC SPECIES OF CHEILOSTOMATA.}

SiR,-My attention has been drawn to Mr. Edwin A. Walford's articles "On some Bryozoa from the Inferior Oolite of Shipton Gorge," and "On Cheilostomatous Bryozoa from the Middle Lias," both of which were published in the Quarterly Journal of the Geological Society, Vol. L., February, 1894, pp. 72-82.

I regret that I have omitted to make a reference to Mr. Walford's papers in an article published by me, "On some Jurassic species of Cheilostomata" in the Grological Magazine for February, 1894, pp. 61-64; but at that time Mr. Walford's papers were unpublished save for the abstracts which had appeared in April and June, 1893, during my absence in East Africa. $\quad J$. W. Gregory.

ERRata.-Sir H. H. Howorth begs us to correct the following errata in his article in the June Number of this MAGAZINE :-

On p. 260, line 41 from top, for "Hampshire" read Sussex.

On p. 262, line 8 from top, for "Micael" read Michel.

On p. 262 , line 31 from top, delete the words " among them." 